\title{
Analisis Perbandingan Algoritma Simple Additive Weighting dan Fuzzy dalam Sistem Pendukung Keputusan
}

\author{
Heri Abijono ${ }^{1}$ \\ ${ }^{1}$ Sekolah Tinggi Teknologi Cahaya Surya Kediri \\ 1ahabijono@gmail.com
}

\begin{abstract}
Abstrak
Suatu sistem pendukung keputusan (SPK) untuk pendistribusian dana Bantuan Siswa Miskin telah peneliti terapkan di tahun 2015 dengan menggunakan metode Simple Additive Weighting. Sistem ini kemudian dikembangkan di tahun 2017 dengan menambahkan ketentuan kepemilikan Kartu Perlindungan Sosial ataupun Surat Keterangan Miskin oleh orangtua/wali siswa sebagai pertimbangan prioritas pemberian dana bantuan itu selain mempertimbangkan empat macam kriteria yang telah ada pada sistem sebelumnya. Keluaran sistem adalah berupa informasi perankingan prioritas siswa untuk memperoleh dana Bantuan Siswa Miskin. Penelitian saat ini dimaksudkan untuk membandingkan metode Simple Additive Weighting dengan metode Fuzzy dalam menangani permasalahan pendistribusian dana Bantuan Siswa Miskin untuk menentukan metode mana yang cocok dipakai pada permasalahan ini. Analisis berupa perhitungan-perhitungan untuk tiap-tiap metode yang diperbandingkan dijelaskan pada penelitian ini untuk mengetahui cara kerja proses dari tiap-tiap metode yang diperbandingkan..
\end{abstract}

Kata Kunci-Bantuan Siswa, Fuzzy, SAW, SPK.

\section{PENDAHULUAN}

Bantuan Siswa Miskin (BSM) merupakan program bantuan dana dari pemerintah yang dibagikan secara merata kepada para siswa miskin. Prioritas utama diberikan kepada siswa yang orangtua/wali siswa tersebut memiliki Kartu Perlindungan Sosial (KPS) ataupun Surat Keterangan Miskin (SKM) dari Kantor Desa/Kelurahan sesuai domisili orangtua/wali siswa. Dana BSM juga dibagikan kepada para siswa yang orangtua/walinya tidak memiliki KPS ataupun SKM dengan syarat mengisi angket dari pihak sekolah dan mengembalikan angket itu ke sekolah. Angket ini berisi pertanyaanpertanyaan yang membutuhkan jawaban dari orangtua/wali siswa. Pertanyaanpertanyaan ini merupakan kriteria-kriteria yang akan diuji dan pilihan-pilihan jawaban pada setiap pertanyaan memiliki nilai bobot yang mempengaruhi hasil dari proses perhitungan untuk menentukan nilai persentase prioritas/peluang siswa dalam menerima dana BSM. Dalam kenyataannya dapat terjadi bahwa hasil jawaban angket dari orangtua/wali siswa justru tidak dipakai sebagai dasar pengambilan keputusan, sebab telah dicampuri dengan pertimbangan-pertimbangan subjektif dari oknum panitia penyaluran BSM ketika akan membagikan dana BSM itu kepada para siswa, sehingga ada siswa miskin malah tidak mendapat dana BSM, sebaliknya ada siswa dengan kategori orangtua/wali yang memiliki keuangan cukup namun dapat menerima dana BSM. 
Kemiskinan merupakan ketidakmampuan dari sisi ekonomi untuk memenuhi kebutuhan pokok minimum (basic need approach) baik pangan maupun non pangan semisal sandang, pangan, kesehatan, erumahan, dan pendidikan yang diperlukan untuk bisa hidup dan bekerja. Kemiskinan dipandang sebagai ketidakmampuan diukur dari sisi pengeluaran, sehingga penduduk miskin adalah penduduk yang tidak mampu memenuhi kebutuhan pokok dengan rata-rata pengeluaran perkapita di bawah garis kemiskinan (GK) [1].

Kartu Perlindungan Sosial (KPS) adalah kartu yang diterbitkan oleh Pemerintah sebagai penanda rumah tangga miskin. KPS dirancang sebagai penanda universal bagi Rumah Tangga Sasaran (RTS) untuk mengakses program perlindungan. memuat informasi: Nama Kepala Rumah Tangga, Nama Pasangan Kepala Rumah Tangga, Nama Anggota Rumah Tangga Lain, Alamat Rumah Tangga, Nomor Kartu Keluarga, dilengkapi dengan kode batang (barcode) beserta nomor identitas KPS yang unik. Kartu Perlindungan Sosial berguna untuk mendapatkan program subsidi beras (RASKIN), Bantuan Siswa Miskin (BSM), Bantuan Langsung Tunai (BLT), dan bantuan-bantuan yang lain [2].

Pemilihan metode logika mana yang cocok diterapkan dalam sistem pengambilan keputusan untuk menyelesaikan suatu permasalahan memiliki peranan penting sebab harus disesuaikan dengan aturan/ketentuan yang sedang berlaku saat ini maupun hasil keluaran yang diinginkan oleh pihak sekolah. Hal ini mendorong peneliti untuk melakukan perbandingan metode Simple Additive Weighting dengan metode logika Fuzzy dalam pencarian solusi dari permasalahan pendistribusian dana BSM ini.

Beberapa jurnal penelitian yang telah membahas mengenai metode-metode yang dipakai di dalam sistem pengambilan keputusan adalah:

Perbandingan dua metode, yaitu Fuzzy Multi-Attribute Decision Making (FMADM) dan Fuzzy Multi-Criteria Decision Making (FMACM) telah diteliti untuk menganalisis sistem pendukung keputusan dalam memilih program studi. Penelitian ini menarik dan dapat memberi motivasi kepada peneliti sebab penelitiaan ini melakukan perbandingan dua metode sistem pendukung keputusan untuk penyelesaian sebuah kasus pememilihan program studi.

Suatu penelitian dengan menggunakan metode Simple Additive Weighting untuk menentukan kelayakan lokasi pembangunan tower pemancar sinyal. Penelitian ini memotivasi peneliti karena memakai kriteria-kriteria pengujian untuk menilai dan membandingkan satu calon lokasi dengan calon lokasi yang lain untuk memilih lokasi yang tepat untuk membangun tower Base Transceiver Station (BTS) baru yang potensial agar sinyal dari tower tersebut dapat menjangkau wilayah pelanggan.

Sebuah penelitian dengan hasil berupa suatu sistem pendukung keputusan untuk menentukan penilaian Good Governance pada suatu kabupaten menggunakan algoritma Simple Additive Weighting pula. Peneliti tertarik dengan penelitian ini sebab di dalamnya ditentukan bobot kriteria dengan menentukan tingkat kepentingan nilai bobot kriteria yang satu terhadap nilai bobot kriteria lainnya dan melakukan penilaian masingmasing alternatif yang tersedia terhadap masing-masing kriteria yang ada.

Persoalan pemilihan penerima KPS telah diteliti dengan menggunakan Fuzzy Inference System Metode Tsukamoto. Hal menarik dari penelitian ini adalah mengenai penentuan variabel-variabel yang diuji mengacu kepada kriteria-kriteria pada persoalan, dan tiap-tiap variabel memiliki keanggotaan himpunan yang kemudian diuji di dalam proses pengambilan keputusan. Persoalan lain untuk menentukan kedalaman dan jenis tanah juga telah diteliti dengan menggunakan Fuzzy Tsukamoto. Dari penelitian ini peneliti dapat mengetahui bahwa formula untuk pengambilan keputusan dapat dibentuk 
dengan menggunakan instruksi $I F$, selain menggunakan query statement pada penelitian lain yang sama-sama menggunakan metode Fuzzy.

Berdasarkan penelitian-penelitian yang telah dilakukan seperti disebutkan pada alinea di atas, penelitian kali ini ditujukan untuk melakukan perbandingan cara kerja algoritma metode Simple Additive Weighting dengan metode Fuzzy untuk mencari solusi atas permasalahan penyaluran dana BSM ini. Dua tujuan utama yang dapat diperoleh dari penelitian ini adalah:

a. Untuk menganalisis suatu sistem pendukung keputusan yang memberikan alternatif [3] perankingan siswa calon penerima dana BSM.

b. Untuk mendapatkan hasil perbandingan antara kedua metode tersebut dalam memilih [3] urutan prioritas siswa dalam menerima dana BSM itu.

\section{METODE PENELITIAN}

\subsection{Jenis, Sifat, dan Pendekatan Penelitian}

Penelitian yang dilakukan ini memiliki jenis penelitian tindakan, yaitu peneliti memulai dengan mengumpulkan angket yang telah dijawab oleh orangtua/wali siswa dan peneliti memberi nilai bobot untuk tiap-tiap jawaban pada angket. Nilai bobot baku untuk setiap kriteria telah ditetapkan oleh pihak sekolah.

Penelitian ini bersifat deskriptif yaitu mendeskripsikan kegiatan penelitian dari tahap awal, melakukan analisis perhitungan, sampai membuat suatu kesimpulan berdasarkan kejadian nyata pada kegiatan penyaluran dana BSM kepada para siswa oleh Panitia BSM di SMP Negeri 6 Kabupaten Nganjuk (SMPN 6 Nganjuk).

Pendekatan penelitian ini adalah bersifat kualitatif, yaitu memahami cara kerja algoritma tiap-tiap metode dalam sistem pengambilan keputusan yang akan dibandingkan, kemudian algoritma itu dipakai untuk pemrosesan pengambilan keputusan sampai menghasilkan keluaran berupa hasil perankingan prioritas siswa dalam menerima dana BSM.

\subsection{Metode Pengumpulan Data}

Pengumpulan data pada penelitian ini dengan cara:

a. Dengan seizin Kepala SMPN 6 Nganjuk peneliti melakukan observasi dan wawancara dengan anggota tim Panitia Penyaluran Dana BSM. Melalui kegiatan ini peneliti dapat mengetahui aturan-aturan mengenai penyaluran dana BSM kepada para siswa dan kriteria-kriteria yang menjadi bahan pertimbangan panitia dalam menyalurkan dana BSM.

Aturan-aturan pendistribusian dana BSM kepada para siswa meliputi:

1) Dana BSM dibagikan secara merata kepada seluruh siswa.

2) Para orangtua/wali siswa yang memiliki KPS ataupun dapat menunjukkan SKM mendapat prioritas pertama untuk menerima dana BSM.

3) Angket rekomendasi penerimaan dana BSM dari sekolah dibagikan khusus kepada para orangtua/wali siswa yang tidak memiliki KPS/SKM.

4) Orangtua/wali siswa mengisi angket itu dan mengembalikannya kepada Panitia Penyaluran Dana BSM, untuk keperluan pemrosesan penyaluran dana BSM.

5) Orangtua/wali siswa yang tidak mengisi angket itu ataupun tidak mengembalikan angket itu kepada Panitia Penyaluran Dana BSM, mereka tetap dapat menerima dana BSM pada urutan terakhir setelah dana BSM dibagikan kepada grup orangtua/wali siswa yang memiliki KPS/SKM dan grup orangtua/wali siswa yang mengembalikan angket itu kepada Panitia Penyaluran Dana BSM. 
Tabel 1 memuat kriteria-kriteria yang ditetapkan oleh Panitia Penyaluran Dana BSM SMPN 6 Nganjuk dalam pendistribusian dana BSM.

Tabel 1. Kriteria dan Bobot yang Ditetapkan

\begin{tabular}{|l|l|r|}
\hline Nama & \multicolumn{1}{|c|}{ Keterangan } & Bobot \\
\hline K1 & Penghasilan orangtua/wali rumah & $35 \%$ \\
\hline K2 & $\begin{array}{l}\text { Keadaan bangunan } \\
\text { orangtua/wali }\end{array}$ \\
\hline K3 & Jumlah saudara siswa & $15 \%$ \\
\hline K4 & $\begin{array}{l}\text { Jumlah anak yang masih menjadi } \\
\text { tanggungan orangtua }\end{array}$ & $15 \%$ \\
\hline
\end{tabular}

Ditetapkan juga oleh pihak panitia bahwa kriteria K1 dan kriteria K2 memiliki beberapa pilihan dan nilai seperti yang ditulis pada Tabel 2 dan Tabel 3.

Tabel 2. Nilai untuk Kriteria K1

\begin{tabular}{|l|c|}
\hline \multicolumn{1}{|c|}{ Batasan Penghasilan Per Bulan } & Nilai \\
\hline Kurang dari Rp 500.000,00 & 10 \\
\hline Antara Rp 500.000,00 - Rp & 6 \\
$1.000 .000,00$ & \\
\hline Antara Rp 1.000.000,00 - Rp & 4 \\
$2.000 .000,00$ & \\
\hline Rp 2.000.000,00 & 2 \\
\hline
\end{tabular}

Tabel 3. Nilai untuk Kriteria K2

\begin{tabular}{|l|r|}
\hline $\begin{array}{c}\text { Keadaan Bangunan Rumah } \\
\text { Orangtua/Wali }\end{array}$ & Nilai \\
\hline Rumah sangat sederhana (RSS) & 10 \\
\hline Rumah sederhana (RSd) & 8 \\
\hline Rumah standar (RSt) & 4 \\
\hline Rumah mewah (RM) & 2 \\
\hline
\end{tabular}

Gambar 1 menunjukkan bentuk angket yang dipakai untuk meminta jawaban dari orangtua/wali yang tidak memiliki KPS/SKM. Dalam angket dibuat pertanyaan yang berkaitan dengan kriteria $\mathrm{K} 3$ dan kriteria $\mathrm{K} 4$ yang harus diisi orangtua/wali siswa dengan suatu nilai angka sesuai dengan jumlah saudara siswa dan jumlah anak yang masih menjadi tanggungan orangtua siswa. 


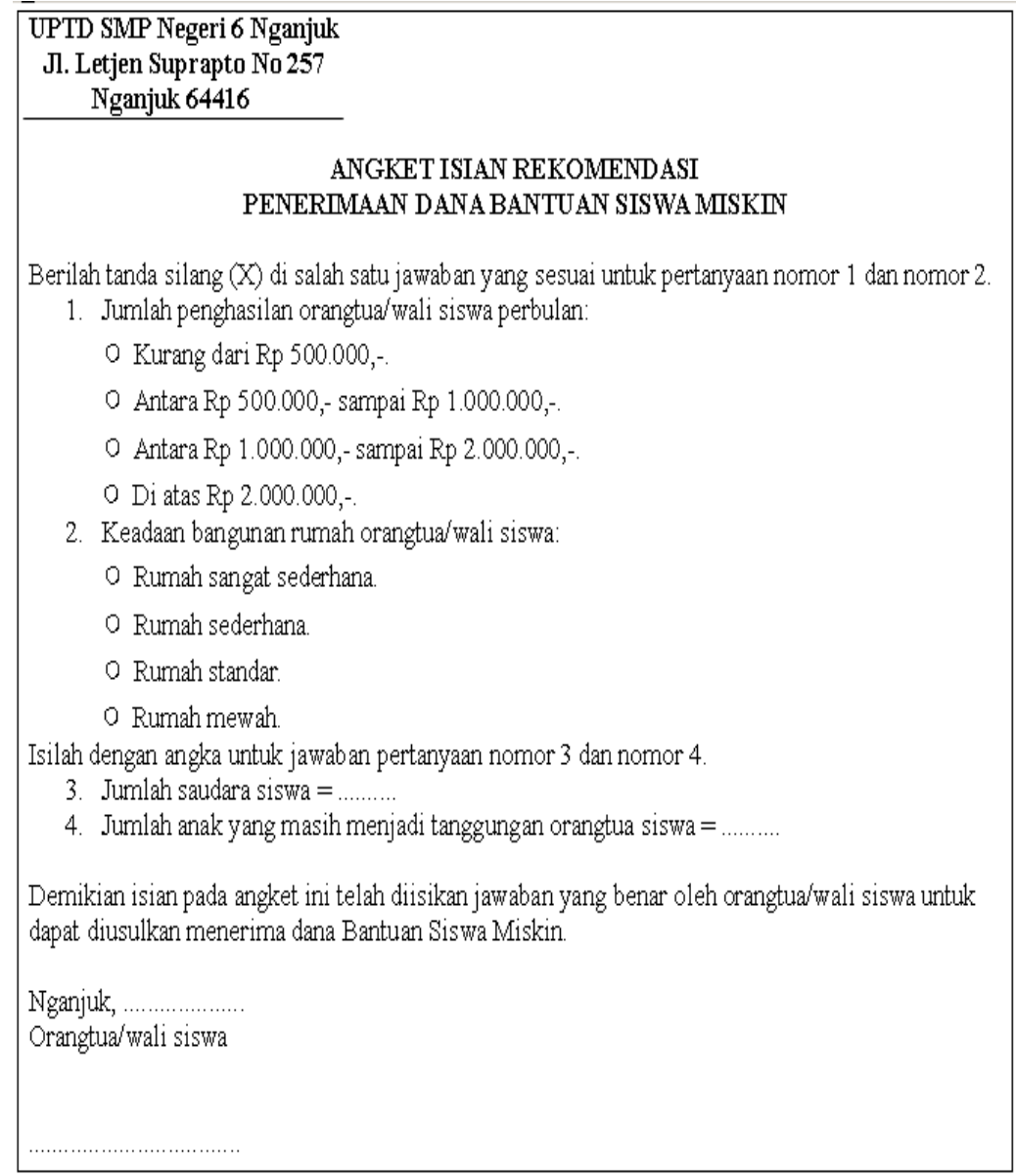

b. Wawancara lain yang telah dilakukan oleh peneliti dengan Tim Panitia Penyaluran Dana BSM adalah mengenai pemrosesan data dari perolehan jawaban pada angket di Gambar 1 sampai menghasilkan perankingan nama para siswa yang berhak mendapatkan dana BSM. Dari kegiatan ini peneliti dapat melihat worksheet Microsoft Excell yang dipakai oleh panitia tersebut adalah dengan cara menjumlahkan langsung nilai-nilai pada tiap-tiap jawaban dalam angket itu untuk mendapatkan nilai prioritas siswa dalam menerima dana BSM.

c. Peneliti juga melakukan wawancara dengan para orangtua/wali murid untuk mengetahui sejauh mana mereka memahami isi pertanyaan pada angket itu dan untuk mengetahui apakah mereka mengalami kebingungan atau tidak ketika memberikan jawaban pada angket itu.

d. Hasil observasi dan wawancara ini peneliti memahami bahwa kriteria-kriteria yang ditulis pada Tabel 1 dapat dijadikan sebagai kriteria-kriteria yang akan diuji oleh metode-metode sistem pendukung keputusan yang dibahas dalam penelitian ini. Acuan nilai bobot untuk Kriteria 1 dapat peneliti ambil dari data pada Tabel 2 dan acuan nilai bobot untuk Kriteria 2 dapat peneliti ambil dari data pada Tabel 3. Sehingga nanti alur perhitungan pengambilan keputusan melalui metode-metode yang dibahas dalam penelitian ini mengacu kepada data dari Tabel 1 sampai Tabel 3 khusus untuk perankingan prioritas siswa penerima BSM dari grup orangtua/wali yang mengisi dan mengembalikan angket kepada Panitia Penyaluran Dana BSM di sekolah ini. 


\section{HASIL DAN PEMBAHASAN}

Tabel 4 berisi data penilaian dari tiap-tiap kriteria atas jawaban angket yang telah terkumpul dari orangtua/wali siswa.

Tabel 4. Hasil Penilaian terhadap Jawaban Angket

\begin{tabular}{|l|l|r|r|r|r|}
\hline \multicolumn{1}{c|}{$\begin{array}{c}\text { Nama } \\
\text { Siswa }\end{array}$} & \multirow{2}{*}{ KPS/ } & \multicolumn{4}{c|}{ Nilai Kriteria } \\
\cline { 3 - 6 } & SKM & K1 & K2 & K3 & K4 \\
\hline Prasetyo & $\mathrm{T}$ *) & 10 & 8 & 3 & 2 \\
\hline Beny & $\mathrm{T}$ & 6 & 10 & 2 & 1 \\
\hline Srinatun & $\mathrm{T}$ & 4 & 4 & 1 & 0 \\
\hline Eko & $\mathrm{T}$ & 2 & 4 & 2 & 1 \\
\hline Sri & $\mathrm{T}$ & 10 & 8 & 3 & 2 \\
\hline Wahyuni & $\mathrm{T}$ & 6 & 10 & 2 & 1 \\
\hline Ninik & $\mathrm{Y} *)$ & 10 & 8 & 3 & 2 \\
\hline Indah & $\mathrm{Y}$ & 6 & 10 & 2 & 1 \\
\hline Ardian & $\mathrm{Y}$ & 2 & 4 & 2 & 1 \\
\hline Pongki & $\mathrm{Y}$ & 6 & 10 & 5 & 3 \\
\hline *) T = Tidak; Y = Ya. & & \multicolumn{4}{|c}{} \\
\hline
\end{tabular}

Para siswa dengan orangtua/wali memiliki KPS/SKM mendapat prioritas pertama menerima dana BSM, sehingga pencarian solusi melalui penyelesaian dengan metode Simple Additive Weighting dan Fuzzy di bawah ini dikhususkan untuk perankingan urutan siswa yang tidak memiliki KPS/SKM.

\subsection{Pencarian Solusi dengan Metode Simple Additive Weighting}

Metode Simple Additive Weighting sering juga dikenal dengan istilah metode penjumlahan terbobot [4]. Cara kerja metode Simple Additive Weighting adalah dengan mencari penjumlahan terbobot dari rating kinerja pada setiap alternatif pada semua atribut, metode ini juga membutuhkan proses normalisasi matriks keputusan (X) ke suatu skala yang dapat diperbandingkan dengan semua rating alternatif yang ada. Proses normalisasi didapat untuk tiap kolom kriteria dengan membaginya dengan nilai kolom kriteria yang tertinggi dalam kolom matriks tersebut [5]. Perhitungan untuk mencari nilai persentase prioritas siswa untuk memperoleh dana BSM dengan metode Simple Additive Weighting terdiri dari langkah-langkah di bawah ini:

A. Mencari nilai normalisasi setiap siswa untuk setiap kriteria (K1 sampai K4)

Nilai n untuk Prasetyo (siswa pertama) dapat diperinci untuk kriteria K1, K2, K3, dan K4 sebagai berikut:

Untuk kriteria K1:

$$
\begin{aligned}
\mathrm{n}_{11} & =\mathrm{K} 1_{1} / \max \left\{\mathrm{K} 1_{1}, \mathrm{~K} 1_{2}, \mathrm{~K} 1_{3}, \ldots \mathrm{K} 1_{10}\right\} . \\
& =10 / \max \{10 ; 6 ; 4 ; 2 ; 10 ; 6 ; 10 ; 6 ; 2 ; 6\} \\
& =10 / 10=1 .
\end{aligned}
$$

Untuk kriteria K2:

$$
\begin{aligned}
\mathrm{n}_{12} & =\mathrm{K} 2_{1} / \max \left\{\mathrm{K} 2_{1}, \mathrm{~K} 2_{2}, \mathrm{~K} 2_{3}, \ldots \mathrm{K} 2_{10}\right\} . \\
& =8 / \max \{8 ; 10 ; 4 ; 4 ; 8 ; 10 ; 8 ; 10 ; 4 ; 10\} \\
& =8 / 10=0.8 .
\end{aligned}
$$

Untuk kriteria K3:

$$
\mathrm{n}_{13}=\mathrm{K} 3_{1} / \max \left\{\mathrm{K} 3_{1}, \mathrm{~K} 3_{2}, \mathrm{~K} 3_{3}, \ldots \mathrm{K} 3_{10}\right\} \text {. }
$$


$=3 / \max \{3 ; 2 ; 1 ; 2 ; 3 ; 2 ; 3 ; 2 ; 2 ; 5\}$

$=3 / 5=0.6$.

Untuk kriteria K4:

$$
\begin{aligned}
\mathrm{n}_{14} & =\mathrm{K} 4_{1} / \max \left\{\mathrm{K} 4_{1}, \mathrm{~K} 4_{2}, \mathrm{~K} 4_{3}, \ldots \mathrm{K} 4_{10}\right\} . \\
& =2 / \max \{2 ; 1 ; 0 ; 1 ; 2 ; 1 ; 2 ; 1 ; 1 ; 3\} \\
& =2 / 3=0.7 .
\end{aligned}
$$

Melalui cara perhitungan yang sama seperti mencari nilai $\mathrm{n}$ untuk siswa pertama kemudian dapat dicari nilai $\mathrm{n}$ untuk untuk siswa kedua sampai siswa keenam untuk setiap kriteria (K1 sampai K4) dengan perincian sebagai berikut:

$\mathrm{n}_{21}=\mathrm{K} 1_{2} / \max \left\{\mathrm{K} 1_{1}, \mathrm{~K} 1_{2}, \mathrm{~K} 1_{3}, \ldots \mathrm{K} 1_{10}\right\}$.

$=6 / \max \{10 ; 6 ; 4 ; 2 ; 10 ; 6 ; 10 ; 6 ; 2 ; 6\}$

$=6 / 10=0.6$.

$\mathrm{n}_{22}=\mathrm{K} 2_{2} / \max \left\{\mathrm{K} 2_{1}, \mathrm{~K} 2_{2}, \mathrm{~K} 2_{3}, \ldots \mathrm{K} 2_{10}\right\}$.

$=10 / \max \{8 ; 10 ; 4 ; 4 ; 8 ; 10 ; 8 ; 10 ; 4 ; 10\}$

$=10 / 10=1$.

$\mathrm{n}_{23}=\mathrm{K} 3_{2} / \max \left\{\mathrm{K} 3_{1}, \mathrm{~K} 3_{2}, \mathrm{~K} 3_{3}, \ldots \mathrm{K} 3_{10}\right\}$.

$=2 / \max \{3 ; 2 ; 1 ; 2 ; 3 ; 2 ; 3 ; 2 ; 2 ; 5\}$

$=2 / 5=0.4$.

$\mathrm{n}_{24}=\mathrm{K} 4_{2} / \max \left\{\mathrm{K} 4_{1}, \mathrm{~K} 4_{2}, \mathrm{~K} 4_{3}, \ldots \mathrm{K} 4_{10}\right\}$.

$=1 / \max \{2 ; 1 ; 0 ; 1 ; 2 ; 1 ; 2 ; 1 ; 1 ; 3\}$

$=1 / 3=0.3$.

$\mathrm{n}_{31}=4 / \max \{10 ; 6 ; 4 ; 2 ; 10 ; 6 ; 10 ; 6 ; 2 ; 6\}$

$=4 / 10=0.4$.

$\mathrm{n}_{32}=4 / \max \{8 ; 10 ; 4 ; 4 ; 8 ; 10 ; 8 ; 10 ; 4 ; 10\}$

$=4 / 10=0.4$.

$\mathrm{n}_{33}=1 / \max \{3 ; 2 ; 1 ; 2 ; 3 ; 2 ; 3 ; 2 ; 2 ; 5\}$

$=1 / 5=0.2$.

$\mathrm{n}_{34}=0 / \max \{2 ; 1 ; 0 ; 1 ; 2 ; 1 ; 2 ; 1 ; 1 ; 3\}$

$=0 / 3=0$.

$\mathrm{n}_{41}=2 / \max \{10 ; 6 ; 4 ; 2 ; 10 ; 6 ; 10 ; 6 ; 2 ; 6\}$

$=2 / 10=0.2$.

$\mathrm{n}_{42}=4 / \max \{8 ; 10 ; 4 ; 4 ; 8 ; 10 ; 8 ; 10 ; 4 ; 10\}$

$=4 / 10=0.4$.

$\mathrm{n}_{43}=2 / \max \{3 ; 2 ; 1 ; 2 ; 3 ; 2 ; 3 ; 2 ; 2 ; 5\}$

$=2 / 5=0.4$.

$\mathrm{n}_{44}=1 / \max \{2 ; 1 ; 0 ; 1 ; 2 ; 1 ; 2 ; 1 ; 1 ; 3\}$

$=1 / 3=0.3$.

$\mathrm{n}_{51}=10 / \max \{10 ; 6 ; 4 ; 2 ; 10 ; 6 ; 10 ; 6 ; 2 ; 6\}$

$=10 / 10=1$.

$\mathrm{n}_{52}=8 / \max \{8 ; 10 ; 4 ; 4 ; 8 ; 10 ; 8 ; 10 ; 4 ; 10\}$

$=8 / 10=0.8$.

$\mathrm{n}_{53}=3 / \max \{3 ; 2 ; 1 ; 2 ; 3 ; 2 ; 3 ; 2 ; 2 ; 5\}$

$=3 / 5=0.6$.

$\mathrm{n}_{54}=2 / \max \{2 ; 1 ; 0 ; 1 ; 2 ; 1 ; 2 ; 1 ; 1 ; 3\}$

$=2 / 3=0.7$.

$\mathrm{n}_{61}=6 / \max \{10 ; 6 ; 4 ; 2 ; 10 ; 6 ; 10 ; 6 ; 2 ; 6\}$

$=6 / 10=0.6$.

$\mathrm{n}_{62}=10 / \max \{8 ; 10 ; 4 ; 4 ; 8 ; 10 ; 8 ; 10 ; 4 ; 10\}$

$=10 / 10=1$. 


$$
\begin{aligned}
& \mathrm{n}_{63}=2 / \max \{3 ; 2 ; 1 ; 2 ; 3 ; 2 ; 3 ; 2 ; 2 ; 5\} \\
& \quad=2 / 5=0.4 . \\
& \mathrm{n}_{64}=1 / \max \{2 ; 1 ; 0 ; 1 ; 2 ; 1 ; 2 ; 1 ; 1 ; 3\} \\
& \quad=1 / 3=0.3 .
\end{aligned}
$$

B. Menyusun matrik R

Hasil dari proses normalisasi pada langkah (a) kemudian dapat dibentuk suatu matriks R sebagai berikut:

$$
\mathrm{R}=\left(\begin{array}{llll}
1 & 0.8 & 0.6 & 0.7 \\
0.6 & 1 & 0.4 & 0.3 \\
0.4 & 0.4 & 0.2 & 0 \\
0.2 & 0.4 & 0.4 & 0.3 \\
1 & 0.8 & 0.6 & 0.7 \\
0.6 & 1 & 0.4 & 0.3
\end{array}\right)
$$

C. Menghitung nilai $\mathrm{P}$ (priority) untuk tiap siswa

Nilai-nilai pada tiap-tiap baris untuk tiap-tiap kolom pada matriks $\mathrm{R}$ di langkah (b) kemudian dikalikan dengan nilai bobot yang telah ditetapkan untuk tiap-tiap kriteria di Tabel 1 sehingga diperoleh rincian perhitungan di bawah ini:

$$
\begin{aligned}
& \begin{aligned}
\mathrm{P}_{1}(\text { Prasetyo }) & =0.35 * 1+0.35 * 0.8+0.15 * 0.6+0.15 * 0.7 \\
= & 0.35+0.28+0.09+0.105 \\
= & 0.825
\end{aligned} \\
& \mathrm{P}_{2}(\text { Beny })=0.35 * 0.6+0.35 * 1+0.15 * 0.4+0.15 * 0.3 \\
& =0.21+0.35+0.06+0.045 \\
& =0.665 \\
& \mathrm{P}_{3}(\text { Srinatun })=0.35 * 0.4+0.35 * 0.4+0.15 * 0.2+0.15 * 0 \\
& =0.14+0.14+0.03+0 \\
& =0.31 . \\
& \mathrm{P}_{4}(\text { Eko })=0.35 * 0.2+0.35 * 0.4+0.15 * 0.4+0.15 * 0.3 \\
& =0.07+0.14+0.06+0.045 \\
& =0.315 \\
& \mathrm{P}_{5}(\text { Sri })=0.35 * 1+0.35 * 0.8+0.15 * 0.6+0.15 * 0.7 \\
& =0.35+0.28+0.09+0.105 \\
& =0.825 . \\
& \mathrm{P}_{6}(\text { Wahyuni })=0.35 * 0.6+0.35 * 1+0.15 * 0.4+0.15 * 0.3 \\
& =0.21+0.35+0.06+0.045 \\
& =0.665
\end{aligned}
$$

D. Perankingan priority (nilai P)

Hasil perhitungan nilai $\mathrm{P}$ (priority) pada langkah (c) kemudian diurutkan descending sebagai berikut:

$$
\begin{aligned}
& \mathrm{P}_{1}(\text { Prasetyo })=0.825=82.5 \% \\
& \mathrm{P}_{5}(\text { Wahyuni })=0.825=82.5 \% \\
& \mathrm{P}_{2}(\text { Beny })=0.665=66.5 \% \\
& \mathrm{P}_{6}(\text { Sri })=0.665=66.5 \% . \\
& \mathrm{P}_{4}(\text { Eko })=0.315=31.5 \% . \\
& \mathrm{P}_{3}(\text { Srinatun })=0.31=31 \% .
\end{aligned}
$$

E. Solusi lengkap dari metode Simple Additive Weighting 
Tabel 5 menunjukkan informasi lengkap pendistribusian dana BSM sebagai solusi dari metode Simple Additive Weighting dengan menyertakan data siswa yang memiliki KPS/SKM.

Tabel 5. Solusi dari Metode Simple Additive Weighting

\begin{tabular}{|l|l|r|c|}
\hline Nama Siswa & KPS/SKM & Prioritas & Solusi \\
\hline Ninik & Y & Diutamakan & Urutan 1 \\
\hline Indah & Y & Diutamakan & Urutan 1 \\
\hline Ardian & Y & Diutamakan & Urutan 1 \\
\hline Pongki & Y & Diutamakan & Urutan 1 \\
\hline Prasetyo & T & $82.5 \%$ & Urutan 2 \\
\hline Wahyuni & T & $82.5 \%$ & Urutan 2 \\
\hline Beny & T & $66.5 \%$ & Urutan 3 \\
\hline Sri & T & $66.5 \%$ & Urutan 3 \\
\hline Eko & T & $31.5 \%$ & Urutan 4 \\
\hline Srinatun & T & $31 \%$ & Urutan 5 \\
\hline $\begin{array}{l}\text { Setelah para siswa di atas menerima dana BSM, } \\
\text { penyaluran dana BSM kemudian diberikan kepada } \\
\text { para siswa dengan orangtua tidak menjawab angket } \\
\text { kuisioner ataupun tidak mengembalikan angket itu } \\
\text { kepada tim Panitia Penyaluran Dana BSM }\end{array}$ \\
\hline
\end{tabular}

\subsection{Pencarian Solusi dengan Metode Fuzzy}

Logika Fuzzy adalah suatu cara yang tepat untuk memetakan suatu ruang input ke dalam suatu ruang output. Cara memetakan suatu ruang input ke dalam suatu ruang output dapat digunakan beberapa cara, di antaranya sistem Fuzzy, sistem linear, sistem pakar, jaringan syaraf, persamaan differensial, dan tabel interpolasi multidimensi. Dari sekian banyak cara yang telah disebutkan, cara yang lebih tepat dan lebih murah adalah menggunakan Fuzzy. [3]

Pencarian solusi dengan metode Fuzzy terdiri dari langkah-langkah di bawah ini:

a. Menentukan variabel-variabel untuk mewakili keadaan [6]

Berdasarkan data kriteria pada Tabel 1 dapat dibuat empat variabel yaitu Penghasilan, Rumah, Saudara, dan variabel Tanggungan.

b. Proses fuzzyfikasi [7]

Pada proses fuzzyfikasi sistem menghitung nilai derajat keanggotaan masing-masing variabel input yang telah ditentukan [7] pada langkah (a). Pada proses fuzzyfikasi ini dapat dibuat empat macam himpunan berdasarkan variabel-variabel yang telah dibuat pada langkah (a), yaitu:

i) Variabel Penghasilan memiliki tiga himpunan, yaitu Sedikit, Sedang, dan Banyak.

ii) Variabel Rumah memiliki tiga himpunan, yaitu Kelas-1, Kelas-2, dan Kelas-3.

iii) Variabel Saudara memiliki tiga himpunan, yaitu Sedikit, Sedang, dan Banyak.

iv) Variabel Tanggungan memiliki tiga himpunan, yaitu Sedikit, Sedang, dan Banyak.

c. Membuat grafik fungsi keanggotaan untuk tiap-tiap variabel [6]

Berdasarkan data hasil penilaian angket di Tabel 4 untuk kolom K1, himpunan nilainilai untuk variabel Penghasilan dapat meliputi: Sedikit, Sedang, dan Banyak, yang dapat dibuat grafik pada Gambar 2. 


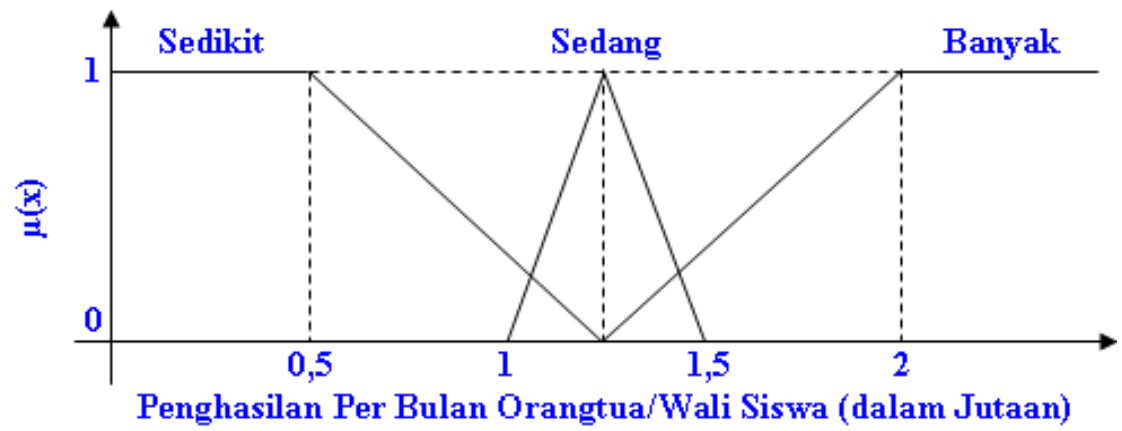

Gambar 2. Grafik Fungsi Keanggotaan untuk Variabel Penghasilan

Dari grafik fungsi pada Gambar 2 dapat dibuat tiga fungsi keanggotaan di bawah ini:

$\mu$ Sedikit $(x)\left\{\begin{aligned} & 1 ; \text { di mana } x \leq 0.5 \\ &(1.25-x) / 0.5 ; \text { dimana } 0.5 \leq x \leq 1.25\end{aligned}\right.$

0 ; di mana $x \geq 1.25$

$\mu \operatorname{Sedang}(\mathrm{x})\left\{\begin{array}{l}0 ; \text { di mana } \mathrm{x} \leq 1 \text { atau } \mathrm{x} \geq 1.5 \\ (\mathrm{x}-1) / 0.25 ; \text { dimana } 1 \leq \mathrm{x} \leq 1.25\end{array}\right.$

$(1.5-x) / 0.25$; di mana $1.25 \leq x \leq 1.5$

$\mu \operatorname{Banyak}(\mathrm{x})\left\{\begin{array}{cc}0 ; & \text { di mana } \mathrm{x} \leq 1.25 \\ (\mathrm{x}-1.25) / 0.5 ; \operatorname{dimana} 1.25 \leq \mathrm{x} \leq 2\end{array}\right.$

1 ; di mana $\mathrm{x} \geq 2$

Berdasarkan derajat keanggotaan pada variabel Penghasilan dapat disusun calon penerima BSM seperti pada Tabel 6.

Tabel 6. Data Calon Penerima BSM berdasarkan Penghasilan Orangtua

\begin{tabular}{|l|c|c|c|}
\hline \multirow{2}{*}{ Nama } & \multicolumn{3}{|c|}{ Derajat Keanggotaan $(\boldsymbol{\mu}[\mathbf{x}])$} \\
\cline { 2 - 4 } & Sedikit & Sedang & Banyak \\
\hline Prasetyo & 1 & 0 & 0 \\
\hline Beny & 0 & 1 & 0 \\
\hline Srinatun & 0 & 1 & 0 \\
\hline Eko & 0 & 0 & 1 \\
\hline Sri & 1 & 0 & 0 \\
\hline Wahyuni & 0 & 1 & 0 \\
\hline Ninik & 1 & 0 & 0 \\
\hline Indah & 0 & 1 & 0 \\
\hline Ardian & 0 & 0 & 1 \\
\hline Pongki & 0 & 1 & 0 \\
\hline
\end{tabular}

Data penilaian angket untuk kolom K2 di Tabel 4, himpunan nilai-nilai untuk variabel Rumah dapat meliputi Kelas-1, Kelas-2, dan Kelas-3, kemudian dapat dibuat grafik seperti pada Gambar 3.

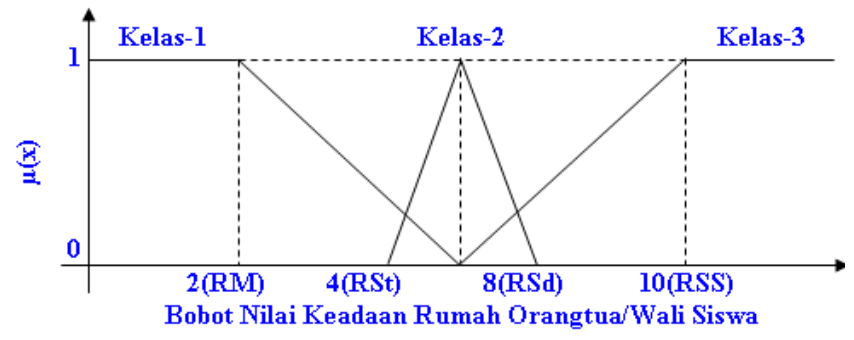

Gambar 3. Grafik Fungsi Keanggotaan untuk Variabel Rumah 
Dari grafik fungsi pada Gambar 3 dapat dibuat tiga fungsi keanggotaan di bawah ini:

$\mu \operatorname{Kelas}-1(\mathrm{x})\left\{\begin{array}{l}0 ; \quad \begin{array}{l}\text { di mana } \mathrm{x} \leq 6 \\ (\mathrm{x}-6) / 2 ; \operatorname{dimana} 2\end{array} \\ 1 ; \mathrm{x} \leq 6\end{array}\right.$

$\mu$ Kelas-2(x) $\begin{cases}0 ; & \text { di mana } 4 \leq \mathrm{x} \leq 8 \\ (\mathrm{x}-4) / 12 ; \text { dimana } 4 \leq \mathrm{x} \leq 6\end{cases}$

$(6-\mathrm{x}) / 1$; di mana $6 \leq \mathrm{x} \leq 8$

$\mu$ Kelas-3(x) $\begin{cases}1 ; & \text { di mana } x \geq 10 \\ & (6-x) / 10 ; \text { dimana } 6 \leq x \leq 10 \\ 0 ; \text { di mana } x \leq 6\end{cases}$

Berdasarkan derajat keanggotaan pada variabel Rumah dapat disusun calon penerima BSM seperti pada Tabel 7.

Tabel 7. Calon Penerima BSM Berdasarkan Keadaan Bangunan Rumah

\begin{tabular}{|l|c|c|c|}
\hline \multirow{2}{*}{ Nama } & \multicolumn{3}{c|}{ Derajat Keanggotaan $(\boldsymbol{\mu}[\mathbf{x}])$} \\
\cline { 2 - 4 } & Kelas-1 & Kelas-2 & Kelas-3 \\
\hline Prasetyo & 0 & 1 & 0 \\
\hline Beny & 0 & 0 & 1 \\
\hline Srinatun & 0 & 1 & 0 \\
\hline Eko & 0 & 1 & 0 \\
\hline Sri & 0 & 1 & 0 \\
\hline Wahyuni & 0 & 0 & 1 \\
\hline Ninik & 0 & 1 & 0 \\
\hline Indah & 0 & 0 & 1 \\
\hline Ardian & 0 & 1 & 0 \\
\hline Pongki & 0 & 0 & 1 \\
\hline
\end{tabular}

Data penilaian angket untuk kolom K3 di Tabel 4 maka himpunan nilai-nilai untuk variabel Saudara dapat meliputi Sedikit, Sedang, dan Banyak, yang dapat dibuat grafik pada Gambar 4.

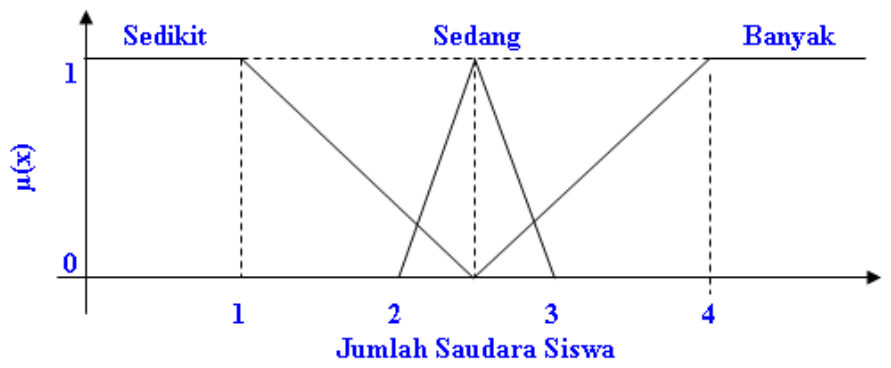

Gambar 4. Grafik Fungsi Keanggotaan untuk Variabel Saudara

Grafik fungsi pada Gambar 4 dapat dibuat tiga fungsi keanggotaan di bawah ini:

0 ; di mana $\mathrm{x} \leq 2.5$.

$\mu \operatorname{Sedikit}(\mathrm{x})=(\mathrm{x}-2.5) / 1 ; \operatorname{dimana} 1 \leq \mathrm{x} \leq 2.5$.

1 ; di mana $x \geq 1$.

0 ; di mana $2 \leq \mathrm{x} \leq 3$.

$\mu \operatorname{Sedang}(\mathrm{x})=(\mathrm{x}-2) / 5$; dimana $2 \leq \mathrm{x} \leq 2.5$.

$(2.5-x) / 0.5$; di mana $2,5 \leq x \leq 3$.

1 ; di mana $x \geq 4$.

$\mu \operatorname{Banyak}(x)=(2.5-x) / 4$; dimana $2.5 \leq x \leq 4$. 
0 ; di mana $\mathrm{x} \leq 2.5$.

Dengan derajat keanggotaan pada variabel Saudara dapat disusun calon penerima BSM seperti pada Tabel 8 .

Tabel 8. Calon Penerima BSM Berdasarkan Jumlah Saudara Siswa

\begin{tabular}{|l|c|c|c|}
\hline \multirow{2}{*}{ Nama } & \multicolumn{3}{|c|}{ Derajat Keanggotaan $(\boldsymbol{\mu}[\mathbf{x}])$} \\
\cline { 2 - 4 } & Sedikit & Sedang & Banyak \\
\hline Prasetyo & 0 & 1 & 0 \\
\hline Beny & 0 & 1 & 0 \\
\hline Srinatun & 1 & 0 & 0 \\
\hline Eko & 0 & 1 & 0 \\
\hline Sri & 0 & 1 & 0 \\
\hline Wahyuni & 0 & 1 & 0 \\
\hline Ninik & 0 & 1 & 0 \\
\hline Indah & 0 & 1 & 0 \\
\hline Ardian & 0 & 1 & 0 \\
\hline Pongki & 0 & 0 & 1 \\
\hline
\end{tabular}

Data penilaian angket untuk kolom K4 maka himpunan nilai-nilai untuk variabel Tanggungan dapat meliputi Sedikit, Sedang, dan Banyak, kemudian dapat dibuat grafik seperti pada Gambar 5.

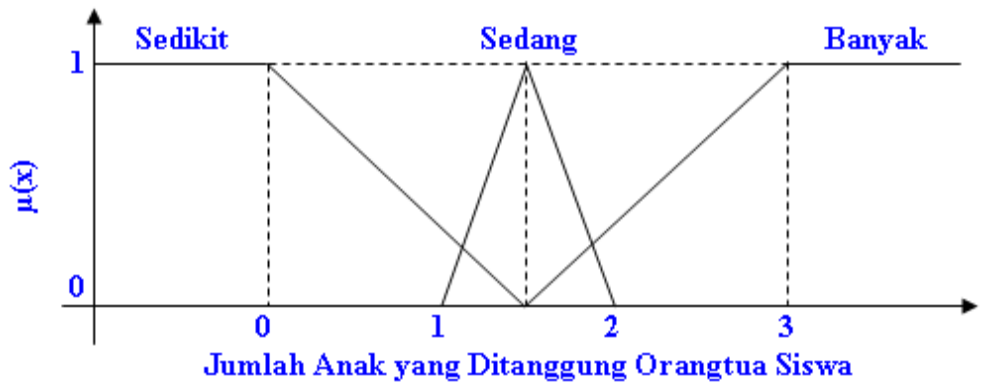

Gambar 5. Grafik Fungsi Keanggotaan untuk Variabel Tanggungan

Grafik fungsi pada Gambar 5 dapat dibuat tiga fungsi keanggotaan di bawah ini:

$\mu \operatorname{Sedikit}(x)\left\{\begin{array}{l}0 ; \text { di mana } x \leq 1.5 . \\ (x-1.5) / 0 ; \text { dimana } 0 \leq x \leq 1.5 .\end{array}\right.$

1 ; di mana $\mathrm{x} \geq 0$.

$\mu \operatorname{Sedang}(\mathrm{x})\left\{\begin{array}{l}0 ; \text { di mana } 1 \leq \mathrm{x} \leq 2 . \\ (\mathrm{x}-1) / 4 ; \text { dimana } 1 \leq \mathrm{x} \leq 1.5 .\end{array}\right.$

$(1.5-x) /-0.5$; di mana $1.5 \leq x \leq 2$

1 ; di mana $\mathrm{x} \geq 3$.

$\mu \operatorname{Banyak}(\mathrm{x})=(1.5-\mathrm{x}) / 3$; dimana $1.5 \leq \mathrm{x} \leq 3$.

0 ; di mana $x \leq 1.5$.

Derajat keanggotaan pada variabel Tanggungan dapat disusun calon penerima BSM seperti pada Tabel 9. 
Tabel 9. Calon Penerima BSM Berdasarkan Jumlah Anak Yang Masih Ditanggung Orangtua

\begin{tabular}{|l|c|c|c|}
\hline \multirow{2}{*}{ Nama } & \multicolumn{3}{|c|}{ Derajat Keanggotaan $(\boldsymbol{\mu}[\mathbf{x}])$} \\
\cline { 2 - 4 } & Sedikit & Sedang & Banyak \\
\hline Prasetyo & 0 & 1 & 0 \\
\hline Beny & 0 & 1 & 0 \\
\hline Srinatun & 1 & 0 & 0 \\
\hline Eko & 0 & 1 & 0 \\
\hline Sri & 0 & 1 & 0 \\
\hline Wahyun & 0 & 1 & 0 \\
\hline Ninik & 0 & 1 & 0 \\
\hline Indah & 0 & 1 & 0 \\
\hline Ardian & 0 & 1 & 0 \\
\hline Pongki & 0 & 0 & 1 \\
\hline
\end{tabular}

d. Membuat query statement untuk membuat keputusan [6]

Informasi-informasi pada Tabel 6 sampai Tabel 9 menjadi pedoman pembuatan beberapa query statement untuk mencari calon penerima dana BSM, misal:

Siapa yang layak menerima dana BSM jika penerima memiliki kriteria jumlah SAUDARA siswa BANYAK, RUMAHnya KELAS-3, PENGHASILAN orangtua SEDIKIT, dan jumlah anak yang menjadi TANGGUNGAN orangtua BANYAK? Maka query statement yang diberikan dapat berupa select Nama from Siswa where (Saudara = "BANYAK") and (Rumah = "KELAS-3") and (Penghasilan = "SEDIKIT") and (Tanggungan = "BANYAK"). Hasil pemrosesan query statement ini ditunjukkan pada Tabel 10.

Tabel 10. Hasil Query-1

\begin{tabular}{|c|c|c|c|c|}
\hline \multirow[b]{2}{*}{ Nama } & \multicolumn{4}{|c|}{ Derajat Keanggotaan $(\mu[\mathrm{x}])$} \\
\hline & $\begin{array}{r}\text { Saudara } \\
\text { BANYAK }\end{array}$ & $\begin{array}{c}\text { Rumah } \\
\text { KELAS-3 }\end{array}$ & \begin{tabular}{|c|} 
Penghasilan \\
SEDIKIT
\end{tabular} & $\begin{array}{c}\text { Tanggungan } \\
\text { BANYAK }\end{array}$ \\
\hline Adi & 0 & 0 & 1 & 0 \\
\hline Beny & 0 & 1 & 0 & 0 \\
\hline Srinatun & 0 & 0 & 0 & 0 \\
\hline Eko & 0 & 0 & 0 & 0 \\
\hline Sri & 0 & 0 & 1 & 0 \\
\hline Wahyuni & 0 & 1 & 0 & 0 \\
\hline Ninik & 0 & 0 & 1 & 0 \\
\hline Indah & 0 & 1 & 0 & 0 \\
\hline Ardian & 0 & 0 & 0 & 0 \\
\hline Pongki & 1 & 1 & 0 & 1 \\
\hline \multicolumn{5}{|c|}{ Solusi } \\
\hline \multicolumn{5}{|c|}{0 and 0 and 1 and $0=0$} \\
\hline \multicolumn{5}{|c|}{0 and 1 and 0 and $0=0$} \\
\hline \multicolumn{5}{|c|}{0 and 0 and 0 and $0=0$} \\
\hline \multicolumn{5}{|c|}{0 and 0 and 0 and $0=0$} \\
\hline \multicolumn{5}{|c|}{0 and 0 and 1 and $0=0$} \\
\hline \multirow{2}{*}{\multicolumn{5}{|c|}{$\begin{array}{l}0 \text { and } 1 \text { and } 0 \text { and } 0=0 \\
0 \text { and } 0 \text { and } 1 \text { and } 0=0\end{array}$}} \\
\hline \multirow{2}{*}{\multicolumn{4}{|c|}{0 and 0 and 1 and $0=0$}} & \\
\hline \multirow{2}{*}{\multicolumn{5}{|c|}{$\begin{array}{l}0 \text { and } 1 \text { and } 0 \text { and } 0=0 \\
0 \text { and } 0 \text { and } 0 \text { and } 0=0\end{array}$}} \\
\hline & & & & \\
\hline \multicolumn{3}{|c|}{0 and 0 and 0 and $0=0$} & $d 1=0$ & \\
\hline
\end{tabular}


Solusi yang diperoleh dari Query-1 adalah tidak ada siswa yang dapat menerima dana BSM.

Sesuai aturan pemerintah disebutkan bahwa dana BSM harus disalurkan kepada semua siswa, untuk itu dapat diberi query statement berupa select Nama from Siswa where (Saudara = "SEDIKIT" or Saudara = "SEDANG" or Saudara = "BANYAK") AND (Rumah = "KELAS-1" or Rumah = "KELAS-2" or Rumah = "KELAS-3”) AND (Penghasilan = "SEDIKIT" or Penghasilan = "SEDANG” or Penghasilan = "BANYAK") and (Tanggungan = "SEDIKIT" or Tanggungan = "SEDANG" or Tanggungan = "BANYAK"). Hasil pemrosesan query statement ini ditunjukkan pada Tabel 11.

Tabel 11. Hasil Query-2

\begin{tabular}{|c|c|c|c|c|}
\hline \multirow[t]{2}{*}{ Nama } & \multicolumn{4}{|c|}{ Derajat Keanggotaan $(\mu[\mathrm{x}])$} \\
\hline & $\begin{array}{c}\text { Saudara } \\
\text { SEDIKIT } \\
\text { atau } \\
\text { SEDANG } \\
\text { atau } \\
\text { BANYAK }\end{array}$ & $\begin{array}{c}\text { Rumah } \\
\text { KELAS-1 } \\
\text { atau } \\
\text { KELAS-2 } \\
\text { atau } \\
\text { KELAS-3 }\end{array}$ & $\begin{array}{l}\text { Penghasilan } \\
\text { SEDIKIT } \\
\text { atau } \\
\text { SEDANG } \\
\text { atau } \\
\text { BANYAK }\end{array}$ & $\begin{array}{c}\text { Tanggungan } \\
\text { SEDIKIT } \\
\text { atau } \\
\text { SEDANG } \\
\text { atau } \\
\text { BANYAK }\end{array}$ \\
\hline Prasetyo & $\begin{array}{c}0 \text { or } 1 \text { or } 0 \\
\quad=1\end{array}$ & $\begin{array}{c}0 \text { or } 1 \text { or } 0 \\
\quad=1\end{array}$ & $\begin{array}{c}1 \text { or } 0 \text { or } 0= \\
1\end{array}$ & 0 or 1 or $0=1$ \\
\hline Beny & $\begin{array}{l}0 \text { or } 1 \text { or } 0 \\
\quad=1\end{array}$ & or 0 or $1=1$ & $\begin{array}{c}0 \text { or } 1 \text { or } 0= \\
1\end{array}$ & 0 or 1 or $0=1$ \\
\hline Srinatun & $\begin{array}{l}1 \text { or } 0 \text { or } 0 \\
\quad=1\end{array}$ & $\begin{array}{l}0 \text { or } 1 \text { or } 0 \\
\quad=1\end{array}$ & $\begin{array}{c}0 \text { or } 1 \text { or } 0= \\
1\end{array}$ & 1 or 0 or $0=1$ \\
\hline Eko & $\begin{array}{c}0 \text { or } 1 \text { or } 0 \\
=1\end{array}$ & $\begin{array}{c}0 \text { or } 1 \text { or } 0 \\
=1\end{array}$ & $\begin{array}{c}0 \text { or } 0 \text { or } 1= \\
1\end{array}$ & 0 or 1 or $0=1$ \\
\hline Sri & $\begin{array}{l}0 \text { or } 1 \text { or } 0 \\
\quad=1\end{array}$ & $\begin{array}{l}0 \text { or } 1 \text { or } 0 \\
\quad=1\end{array}$ & $\begin{array}{c}1 \text { or } 0 \text { or } 0= \\
1\end{array}$ & 0 or 1 or $0=1$ \\
\hline Wahyuni & $\begin{array}{l}0 \text { or } 1 \text { or } 0 \\
\quad=1\end{array}$ & $\begin{array}{l}0 \text { or } 0 \text { or } 1 \\
\quad=1\end{array}$ & $\begin{array}{c}0 \text { or } 1 \text { or } 0= \\
1\end{array}$ & 0 or 1 or $0=1$ \\
\hline Ninik & $\begin{array}{c}0 \text { or } 1 \text { or } 0 \\
\quad=1\end{array}$ & $\begin{array}{c}0 \text { or } 1 \text { or } 0 \\
\quad=1\end{array}$ & $\begin{array}{c}1 \text { or } 0 \text { or } 0= \\
1\end{array}$ & 0 or 1 or $0=1$ \\
\hline Indah & $\begin{array}{c}0 \text { or } 1 \text { or } 0 \\
\quad=1\end{array}$ & $\begin{array}{c}0 \text { or } 0 \text { or } 1 \\
\quad=1\end{array}$ & $\begin{array}{c}0 \text { or } 1 \text { or } 0= \\
1\end{array}$ & 0 or 1 or $0=1$ \\
\hline Ardian & $\begin{array}{l}0 \text { or } 1 \text { or } 0 \\
\quad=1\end{array}$ & $\begin{array}{l}0 \text { or } 1 \text { or } 0 \\
\quad=1\end{array}$ & $\begin{array}{c}0 \text { or } 0 \text { or } 1= \\
1\end{array}$ & 0 or 1 or $0=1$ \\
\hline Pongki & $\begin{array}{l}0 \text { or } 0 \text { or } 1 \\
\quad=1\end{array}$ & $\begin{array}{l}0 \text { or } 0 \text { or } 1 \\
\quad=1\end{array}$ & $\begin{array}{c}0 \text { or } 1 \text { or } 0= \\
1\end{array}$ & 0 or 0 or $1=1$ \\
\hline \multicolumn{5}{|c|}{ Solusi } \\
\hline \multicolumn{5}{|c|}{1 and 1 and 1 and $1=1$} \\
\hline \multicolumn{5}{|c|}{1 and 1 and 1 and $1=1$} \\
\hline \multicolumn{5}{|c|}{1 and 1 and 1 and $1=1$} \\
\hline \multicolumn{5}{|c|}{1 and 1 and 1 and $1=1$} \\
\hline \multicolumn{5}{|c|}{1 and 1 and 1 and $1=1$} \\
\hline \multicolumn{5}{|c|}{1 and 1 and 1 and $1=1$} \\
\hline \multicolumn{5}{|c|}{1 and 1 and 1 and $1=1$} \\
\hline \multicolumn{5}{|c|}{1 and 1 and 1 and $1=1$} \\
\hline \multicolumn{5}{|c|}{1 and 1 and 1 and $1=1$} \\
\hline \multicolumn{5}{|c|}{1 and 1 and 1 and $1=1$} \\
\hline
\end{tabular}


Jadi, dengan memasukkan seluruh derajat keanggotaan dari setiap variabel ke dalam query statement, maka semua siswa dapat menerima dana BSM. Secara terurut dana BSM diberikan kepada seluruh siswa sesuai urutan data siswa pada penilaian angket kuisioner di Tabel 4 namun terlebih dahulu diprioritaskan kepada para siswa yang memiliki KPS/SKM.

Hasil perankingan siswa penerima dana BSM dapat dilihat pada Tabel 17 yang memuat informasi solusi untuk permasalahan perankingan siswa dalam menerima dana BSM yang diperoleh dari metode-metode yang diperbandingkan dalam penelitian ini.

Tabel 12. Hasil Perankingan Siswa Penerima Dana
\begin{tabular}{|l|l|}
\hline \multicolumn{1}{|c|}{ Fuzzy } & \multicolumn{1}{|c|}{$\begin{array}{c}\text { Simple Additive } \\
\text { Weighting }\end{array}$} \\
\hline Ninik & Ninik \\
Indah & Indah \\
Ardian & Ardian \\
Pongki & Pongki \\
Adi & Prasetyo \\
Beny & Wahyuni \\
Srinatun & Beny \\
Eko & Sri \\
Sri & Eko \\
Wahyuni & Srinatun \\
\hline
\end{tabular}

\section{KESIMPULAN}

Metode Simple Additive Weighting maupun metode Fuzzy sama-sama dapat dipakai dalam sistem pendukung keputusan untuk permasalahan pendistribusian dana BSM. Metode Simple Additive Weighting lebih tepat dipakai untuk mencari nilai persentase peluang siswa untuk mendapat dana BSM, dan metode ini merupakan metode yang paling mudah untuk melakukan perhitungan nilai prioritas siswa dalam menerima dana BSM.

Metode Fuzzy fleksibel dalam memberi kriteria pada query statement untuk pemilihan siswa penerima BSM, dan perubahan kriteria query dapat disesuaikan dengan kebutuhan jika sewaktu-waktu ada perubahan kebijakan pihak sekolah. Jika diinginkan semua siswa mendapat dana BSM sesuai peraturan pemerintah dan jika metode Fuzzy dipakai pada sistem pendukung keputusan, maka seluruh derajat keanggotaan pada setiap variabel harus ditulis dalam query statement agar metode ini memberi hasil bahwa seluruh siswa dapat menerima dana BSM.

Status terbaik yang diberikan kepada suatu metode merupakan hal relatif, sebab untuk memilih metode mana yang terbaik dapat dipengaruhi dari jumlah data yang diproses dan apa permasalahan yang sedang diselesaikan oleh metode-metode yang sedang diperbandingkan. Dalam permasalahan dana BSM ini metode Simple Additive Weighting maupun metode Fuzzy merupakan dua metode yang dapat dipakai untuk menyelesaikan permasalahan pendistribusian dana BSM pada SMP Negeri 6 Kabupaten Nganjuk.

Pada penelitian ini belum dibahas mengenai karakteristik data yang dipakai untuk menentukan pemilihan suatu metode yang cocok untuk menyelesaikan permasalahan pendistribusian dana BSM kali ini. Untuk itu diharapkan para peneliti lain dapat menemukan suatu metode yang terbaik untuk permasalahan pendistribusian dana BSM 
ini berdasarkan karakteristik data. Peneliti membandingkan dua buah metode pada penelitian ini untuk mengetahui hasil perankingan prioritas siswa dalam menerima dana BSM. Pada kesempatan yang akan datang diharapkan ada peneliti lain yang dapat mengembangkan penelitian ini dengan membandingkan lebih dari dua metode dalam sistem pengambilan keputusan untuk permasalahan pendistribusian dana BSM ini.

\section{DAFTAR PUSTAKA}

[1] BPS konsep kemiskinan [Online] // bpsjatim. -Tanggal diakses 30 Oktober 2017.

[2] TNP2K, 2015, Penetapan Solusi Masalah Kepesertaan dan Pemutakhiran Data Penerima KPS. Jakarta.

[3] Rohayani, Hetty, 2014, Analisis Sistem Pendukung Keputusan Dalam Memilih Program Studi Menggunakan Metode Logika Fuzzy, Jurnal Sistem Informasi (JSI), VOL. 5, NO. 1.

[4] Sidik, Rohman, 2014, Sistem Pendukung Keputusan dalam Menentukan Kelayakan Lokasi untuk Membangun Tower Pemancar Sinyal menggunakan Metode Simple Additive Weighting (SAW), Pelita Informatika Budi Darma, Volume : VI, Nomor: 1.

[5] Maulany, Gerzon J, 2015, Sistem Pendukung Keputusan untuk Menentukan Penilaian Good Governance pada Suatu Kabupaten menggunakan Algoritma Simple Additive Weighting (SAW), Jurnal Ilmiah Mustek Anim Ha, Vol. 4 No. 1.

[6] Sugianti, 2016, Menentukan Penerima KPS Menggunakan Fuzzy Inference System Metode Tsukamoto, Jurnal Ilmiah Multitek Indonesia, Vol. 10, No. 1.

[7] Harliana, 2017, Penentuan Kedalaman dan Jenis Tanah Berdasarkan Data Sondir dengan Fuzzy Tsukamoto, Jurnal Ilmiah Dasi, vol. 18, no. 2. 